\title{
INNOVATION AND ECONOMIC GROWTH: THE CASE OF SLOVAKIA
}

\author{
Kushtrim Braha, * Artan Qineti, Roman Serenčéš
}

Slovak University of Agriculture in Nitra, Slovakia

\begin{abstract}
The role of innovation in the economic growth is becoming a crucial aspect of the future economic development. Building of the innovativedriven economy requires establishment of supportive macroeconomic environment. It involves interplay among three main factors of innovation: education system, entrepreneurship and governmental institutions. Establishment of the integrated national innovation system is a key priority that assures sustainable economic growth. Slovakia is mobilizing its resources in order to shift its economic growth from efficiency-driven to innovation-driven economic growth. The inflow of the foreign investments and attractive entrepreneurial environment are identified as the main resources of economic growth during the observed period. Additional input in accelerating economic growth brought the accession of the country into the EU. On the other hand, R \& D activities remain weakly supported by the public and private funding. As the result, productivity of the Slovak innovators remains low as well. Over the last decade, only 70 patents annually were granted to the Slovak innovators. Despite the significant improvement of the innovative environment, there is a low share of enterprises applying innovation in their business activities.
\end{abstract}

Keywords: innovation, economic growth, FDI, RD, entrepreneurship

\section{Introduction}

Since the early 1990s, Slovakia went through the fast economic transformation leading its economy to capture a sustainable economic growth. The process of economic transition is resuming successfully, and economic growth reached its peak in the late 2000s. During the last decade, Slovakia estimated the highest economic growth compared to the all transitional countries - achieving 5\% annual GDP growth. The economic growth during the same period was fuelled by the large FDI inflow and successful market reforms. However, the declining inflow of FDl evidenced in the late 2000 s raised the question of the alternative sources for the future economic growth. Therefore, based on the experiences from the developed economies the priority of the Slovak economy requires the designing of the innovation-driven objectives that leads it into a sustained economic growth. Relevance of development of the innovation resources is crucial for the economic growth. Countries are increasingly recognizing the importance of innovation as a driver for GDP growth and many of them are proactively taking measures to create the right infrastructure in facilitating innovation. Countries that build both a foundation of science and technology and a strong innovation infrastructure will experience strong GDP growth and high living standards (Maxwell, 2009).

Slovak governmental institutions recognize the increasing role of innovation in ensuring sustained economic growth. They designed the national innovation strategy and related innovative policies underlining the role of innovation in increasing the national competitiveness and productivity. Creation of the strong linkage between the knowledge, business operations, foreign capital flows and other resources constitute the fundamental part of the governmental approach. However, the main challenge remains how to build the innovation capacities that will assure innovative-driven growth.

One of the most important factors of the innovation-driven growth is undoubtedly education system and its research capability. Therefore, increasing support for the research and development represent one of the avenues to exploit the innovation. In addition, Sykes (2004) underlines that expenditure on $R \& D$ can be considered as an investment in knowledge that can translate it into new technologies and more efficient ways of using existing resources. Insofar as it is successful in these respects, it is therefore plausible that higher $R$ \& $D$ expenditure would result in higher growth rates. However, in the case of Slovakia it seems that $R \& D$ activities remain underutilized. During the last decade only a limited number of patents were granted to the Slovak innovators.

\section{Material and methods}

The main objective of this article is to evidence the impact of innovation into the economic growth. Creation of the business friendly-environment in order to attract the inflow of foreign investments was one of the key sources for the successful economic transition in Slovakia. The important role of FDI is extended on the technological transfer it brought into the Slovak innovative environment. Accordingly, one of the methodological objectives of this thesis is to find out whether the interest of the foreign investors is directed in funding the innovative activities in the Slovak economy. Furthermore, our interest is extended in identifying the degree in which Slovakia achieved the benefit from the technological transfer derived from the up to date FDI inflow. The degree of the public awareness on the importance of innovation in the Slovak economic environment is assessed in terms of empirical evidence concerning the degree of the public (governmental) and private support to the $R \& D$ activities. In line with it, there are assessed innovation indicators such as the volume of the financial support to the $R \& D$ activities (GERD), comparative analysis related to the public and private expenditures in $R \& D$, main areas where the $R \& D$ expenditures were directed and so on. In addition, measuring of the $R \& D$ productivity is assessed by evaluating the number of patents granted to the Slovak innovators in comparison with those of the V4 region and North European countries.

\section{Linear regression analysis: Assessing the role of FDI in economic growth}

Regression model in statistics is simply a way of expressing a quantitative relationship between one variable, usually referred to as the dependent variable and one or more other variables, often referred to as the independent variable or predictor (Good, 2005). Linear regression model is a quantitative one and that different modelling methods have been developed 
to meet the different purposes. Here is applied simple linear regression, whose objective is to predict the expected value of a given dependent variable.

According to Weiers (2008), the simple linear regression model is a linear equation having a $y$-intercept and a slope, with estimates of these population parameters based on sample data and determined by standard formulas. The model is described in terms of the population parameters as follows:

$$
=\beta_{0}+\beta_{1} x_{i}+\varepsilon_{i}
$$

where:

$y_{i} \quad-$ a value of the dependent variable, $y$

$x_{i} \quad$ - a value of the independent variable, $x$

$\beta_{0} \quad-$ the intercept of the regression line

$\beta_{1} \quad$ - the slope of the regression line

$\varepsilon_{i} \quad-$ random error, or residual

In the simple linear regression model, there are just two variables, and. As stated previously, these are called the dependent $(y)$ and independent $(x)$ variables, since a typical purpose for this type of analysis is to estimate or predict what will be for a given value of $x$ (Weiers, 2008). In our case, the dependent variable $(y)$ is identified with the level of income (GDP per capita), and it shows the volume income in the selected regions (V4 region and North European countries). On the other hand, as the independent variable $(x)$ is used the stock of foreign direct investments (FDI per capita), indicating the volume of the FDI inflow into the same regions.

For the purpose of our analyses related to the impact of the FDI in the economic growth, here is adopted the following equation:

$$
\hat{y}=b_{0}+b_{1} x
$$

where:

$\hat{y} \quad$ - the estimated value of the FDI p. c. for a given value of GDP p. c.

$b_{0} \quad$ - the $y$-intercept; this is the value of $y$ where the line intersects the $y$-axis whenever $x=0$

$b_{1} \quad$ - the slope of the regression line

$x \quad-$ a value of FDI inflow stock

\section{Data availability}

The source of the data used in this thesis was assessed from the different global and national institutions. However, the data from the Statistical

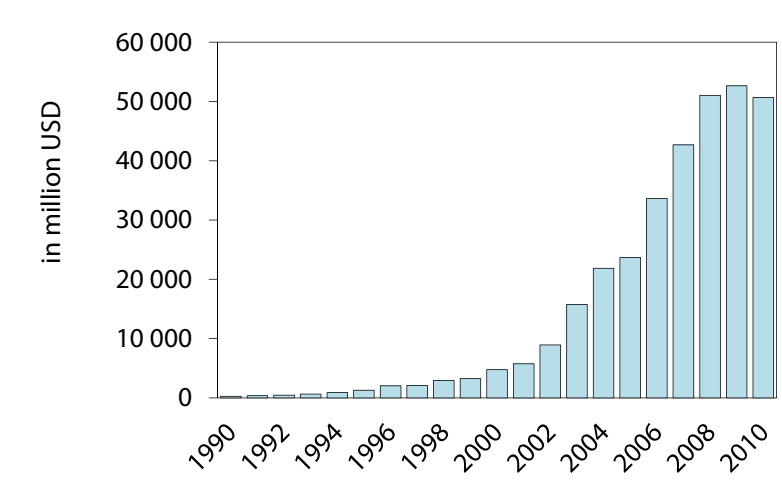

Figure 1 FDl inward stock in SR

Source: Author's calculation based on UNCTAD
Office of the Slovak Republic (SOSR) were the primary source of information enabling us to address the main concerns related to the economic growth and innovation. Accordingly, the data from the global institutions, such as EUROSTAT, World Bank, OECD, World Intellectual Property Organization (WIPO) and World Economic Forum (WEF), were extensively supporting international comparative assessment of innovation-related issues.

\section{Results and discussion}

Foreign direct investment (FDI) contributes to the economic growth of the host economies directly and indirectly. FDI directly supports employment, capital, exports, and new technology in the host country (Blomström et al, 2000). An increasing number of host governments provide various forms of investment incentives to encourage foreign owned companies to invest in their jurisdiction. These include fiscal incentives such as tax holidays and lower taxes for foreign investors, financial incentives such as grants and preferential loans to MNCs, as well as measures like market preferences, infrastructure, and sometimes even monopoly rights (Blomström and Kokko, 2003).

Slovakia is undoubtedly an attractive investment destination. The Slovak Investment and Trade Development Agency (SARI0-b, 2011) lists the advantages of the Slovak economy emphasising the political and economic stability strengthened by the common European currency Euro, simple and fair taxation system, availability of highly skilled and educated workforce, favourable labour costs and flexible Labour Code.

Comparative analysis related to the FDI flow in Slovakia (see Figure 1 and 2) shows that since its early independent existence, it has increased continuously its FDI inward stock. In particular, accession of Slovakia in the EU influenced the accelerated inflow of the foreign investments. The current stock of FDI in Slovakia is estimated to 50.7 billion US\$ (58.1\% of GDP), displaying a double increase since 2004 (23.6 billion US\$). Moreover, since early 2000, Slovakia has accounted an annual average of FDI inflow of 3.8 billion US\$despite the evidence of sharp contraction resulting from the global recession. Such an outcome confirms that Slovakia remained one of the most attractive business environments in the area of the Central and Eastern Europe (CEE).

Foreign investments in Slovakia increased rapidly partly because of its political stability, as well as due to its attractive investment environment after its accession in the EU. However, the pattern of the FDI inflow in Slovakia consequently underlines the sharp disparities concerning the FDI distribution in the regional context. Cumulative FDI inflow for the period 2003-2008 (see Figure 3) highlights the fact that Bratislava region absorbed about two thirds of the total stock of FDI inflow (63.4\%). Just a third (36.6\%) of the FDI inflow

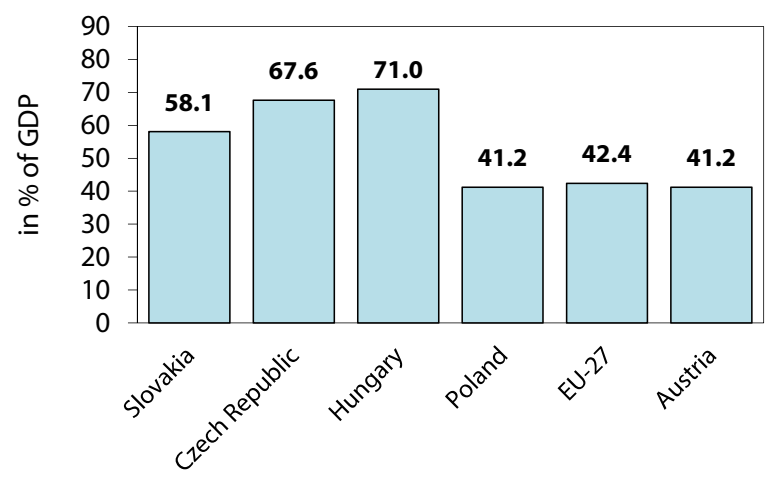

Figure 2 FDl inward stock in \% of GDP Source: Author's calculation based on UNCTAD 


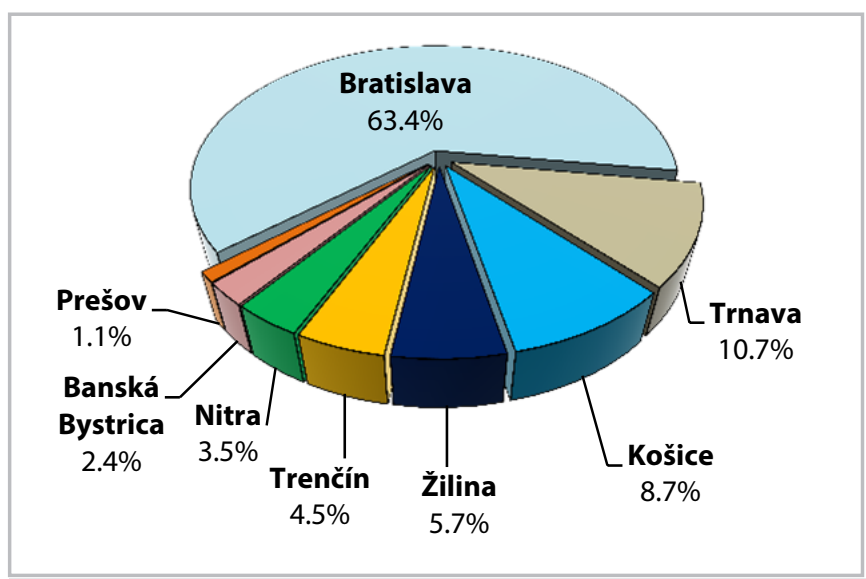

Figure 3 Share of the FDI in Slovakia (cumulative 2003-2008) Source: Author's calculation based on SOSR

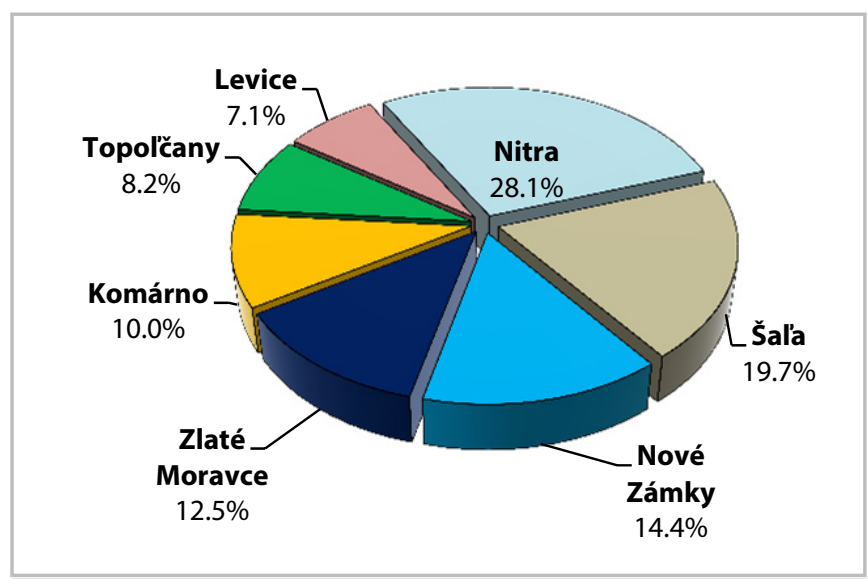

Figure 4 Share of the FDI in Nitra region (cumulative 2003-2008) Source: Author's calculation based on SOSR

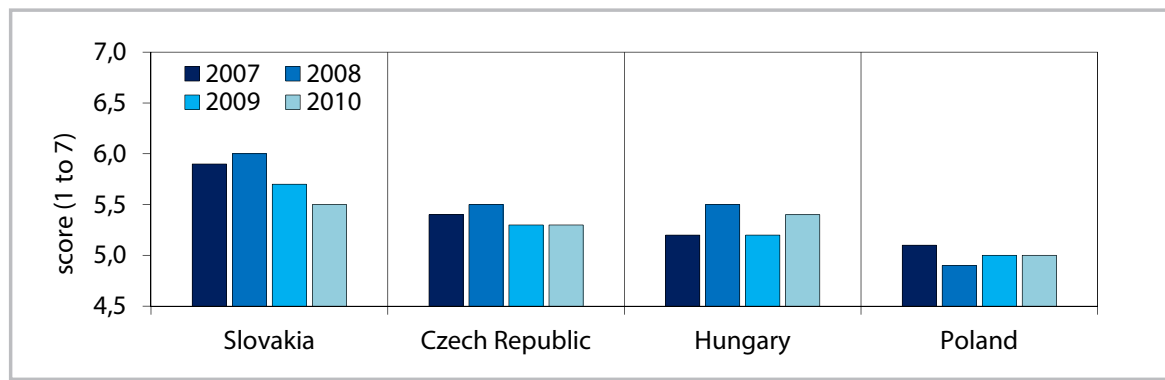

Figure 5 FDl and technology transfer in the V4 countries (2007-2010) Note: To what extent does FDI bring new technology into the country (1 - not at all; 7 - FDl is a key resource of new technology)

Source: Author's calculation based on WEF (Global Competitiveness Reports 2007, 2008, 2009, 2010)
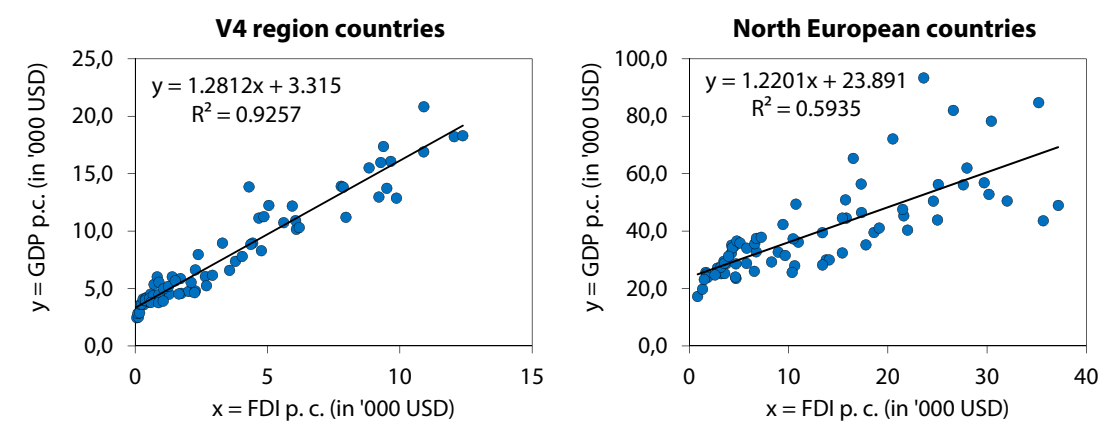

Figure 6 Relationship between FDI and GDP Source: Author's calculation based on UNCTAD

was distributed to the remaining Slovak regions. Despite the occurrence of the sharp disparities in the national level, the intraregional pattern of FDI inflow shows a more proportional distribution. The case of the Nitra region (see Figure 4) affirms that intraregional gap is apparently decreased and the FDI benefits at some level are equally distributed.

The main interest in analyzing the importance of FDI is primarily based on the importance that FDI accelerates in the innovation activities. Opportunities that FDI brings into the domestic economy lay on the creation of the basis for innovation activities. Most importantly, FDI serves as a source for the new technology transfer. Accordingly, the data from the WEF (see Figure 5) emphasise the fact that compared to the other members of the V4 region, Slovakia is the best performing country concerning the FDI and technology transfer (5.8 average score for the period 2007-2010). The ability to absorb and diffuse the technological transfer through the FDI should be considered as one of the major achievements that Slovakia reached in comparison with other transitional countries. In 2010, Slovakia was highly ranked as the $6^{\text {th }}$ best world performing economy gaining from the FDI technology transfer. Taking into account the significant flows of FDI in Slovakia over the last decade, the importance of the FDI in the increasing innovativeness of the national economy remains irreplaceable.

However, taking into account the recent declining FDI inflow in the Slovak economy, the logical question that arises is which are the alternative sources that would assure a sustained economic growth of the Slovak economy over the next period? No doubts, the role of innovation in ensuring the sustained economic growth is crucial.

Importance of the FDI inflow is considered to have a particular importance for the transitional economies such as Slovakia. The role of FDI is directly drawn in the economic growth as well. In order to evidence the impact of the FDI in the economic growth, the simple linear regression analysis was assessed. Regional comparison between the group of the V4 countries and the North European countries confirmed the significant relationship between the stock of the FDI per capita and the GDP per capita. Namely, it shows that income growth is strongly correlated with an increasing intensity of the FDI.

According to the output results of the linear regression model (see Table 1) the coefficient of correlation (Multiple R) shows the existence of the more significant relationship between the FDI and income growth in the case of the V4 region than the North European countries. In the case of the group of $\mathrm{V} 4$ countries (see Figure 6) the model of linear regression explains $92.5 \%$ of the total variability. Based on the regression model there can be assumed that if the FDI stock p.c. would increase for $1 E U R$, the income growth is supposed to increase by 3.315 EUR, meaning that FDI inflow serving as a proxy for the income growth has a relevant impact on the growth of income of the V4 countries. 
Table 1 The output results of the linear regression model: GDP p.c. vs. FDI p. c.

\begin{tabular}{|l|c|c|}
\hline Statistics & V4 region countries & North European Countries \\
\hline Multiple R & 0.96 & 0.77 \\
\hline R Square & 0.92 & 0.59 \\
\hline Adjusted R Square & 0.92 & 0.58 \\
\hline Standard error & $1,281.3$ & $10,177.9$ \\
\hline F-value & 871.59 & 102.18 \\
\hline P-value & 5.75 & 7.86 \\
\hline Observations & 72 & 72 \\
\hline
\end{tabular}

Source: Author's calculation based on WEF

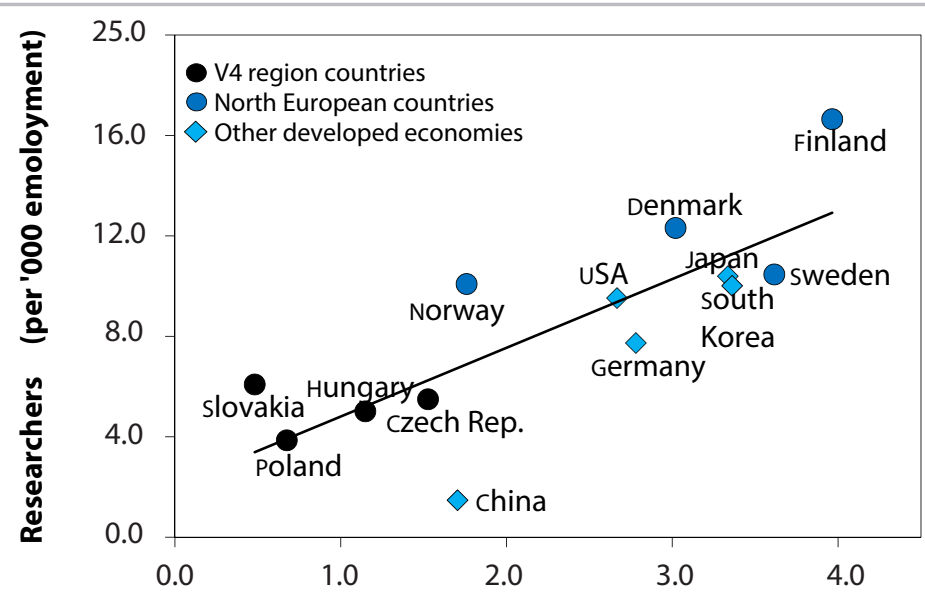

Gross domestic expenditures on R\&D (\% of GDP)

Figure 7 Human capacities and support of the R \& D in selected economies (2010)P Source: Author's calculation based on the OECD

Table 2 R \& D personnel and expenditure in Slovakia and Finland (2004-2010)

\begin{tabular}{|l|c|c|c|c|}
\hline \multirow{2}{*}{ Indicator } & \multicolumn{2}{|c|}{ Slovakia } & \multicolumn{3}{c|}{ Finland } \\
\cline { 2 - 5 } & $\mathbf{2 0 0 4}$ & $\mathbf{2 0 1 0}$ & $\mathbf{2 0 0 4}$ & $\mathbf{2 0 1 0}$ \\
\hline R \& D personnel (Total) & 22,217 & 28,128 & 40,674 & 41,262 \\
\hline - of which women & 9,650 & 12,303 & 8,977 & 8,523 \\
\hline Researchers & 17,354 & 24,049 & 27,182 & 28,025 \\
\hline Total R \& D expenditure in mill. $€$ & 231 & 416 & 3,683 & 4,847 \\
\hline - proportion of public funding in \% & 57.1 & 57.3 & 5.8 & 4.4 \\
\hline
\end{tabular}

Source: Own calculations based on SOSR and SOF data

Comparative analysis between the V4 region and North European countries, as well as some of the most developed economies displays the current position of each single economy concerning the two basic variables of innovative economy: the human resources and intensity of funding of the R \& D. Namely, the main findings (see Figure 7) indicate that Slovakia and other V4 countries are positioned at the bottom concerning the public and private funding to the $R \& D$ activities. Only $0.6 \%$ of GDP is dedicated for the $R \& D$ purposes in Slovakia. Similar result is evidenced in the case of Poland $(0.7 \%)$, while the Czech Republic (1.5\%) and Hungary (1.1\%) tend to display somehow a greater public awareness concerning the support to the $R \& D$. On the other hand, regarding the development of the human resources (number of researchers per thousands of employees), Slovak economy displays somehow a better performance (6.1) in comparison with the other V4 economies. However, the gap between the Slovak R \& D employment and North European countries remains significantly wide.

The case of Finland clearly signifies the path that Slovak economy should follow in order to building a sustainable innovative-driven growth. Achieving employment of more than 16 researchers per thousands of employees (nearly
3 times higher than Slovakia) and dedicating $4.0 \%$ of GDP expenditures on $R \& D$ clearly shows the existing differences between these two economies.

Development of the human capital and in particular the specialised researchers is the most important factor driving the innovation activities. Slovakia estimates the total personnel of 28 thousand persons engaged in the $R$ \& $D$ activities (see Table 2). From them, more than 24 thousands are professional researches performing a different scope of $R \& D$ activities. The most important fact is that the number of researches has been increasing significantly since 2004 , despite the fact that their productivity in terms of granted patents remained relatively low.

Compared to Finland, Slovakia has 10 times lower expenditures on $R \& D$ (see Table 2) despite the fact that the stock of researchers is equivalent in both countries. Concerning the expenditures on $R \& D$ in Slovakia, the outcome of investigation shows a positively rising trend in both percentage and volume share being invested on $R \& D$. By recognizing the potential role of $R$ $\& D$ in sustaining the economic growth, Slovakia increased significantly expenditures dedicated to the $R \& D$ purpose. Since 2004 , expenditures on $R \& D$ were estimated on a double folded increase (see Figure 8). The financing boom of $R \& D$ activities was evidenced in 2010, where expenditures on $R \& D$ were rising from 303 to 416 million EUR.

The major part of $R \& D$ activities in Slovakia is financed by the governmental budget and the EU structural funds - meaning that public financing is the main source of $R \& D$ funding (see Figure 9). In 2010, over 57\% of total R \& D expenditures in Slovakia were financed from the public sources, while the rest of $R \& D$ expenditures were supported by the private sector. There is an indicative fact that since 2004, source of the $R$ $\& D$ funding has been shifting from the private to the public sources. Most obviously, such occurrence was driven by the incoming financial support from the EU structural funds, as well as adoption of the common public EU innovation targets. However, there is overall assumption that $R \& D$ expenditures in Slovakia remain very low $(0.63 \%$ of GDP). Particularly, there must be drawn attention to the role of the private funding of the $R \& D$. Compared to the case of Finland, only $4.4 \%$ of $R \& D$ financing comes from the public sources. Such findings show that innovative activities in Finland are mostly led by the private sector. Hence, it highlights that government's role in supporting innovation-driven economy is not limited only to the public funding. In contrary, it 


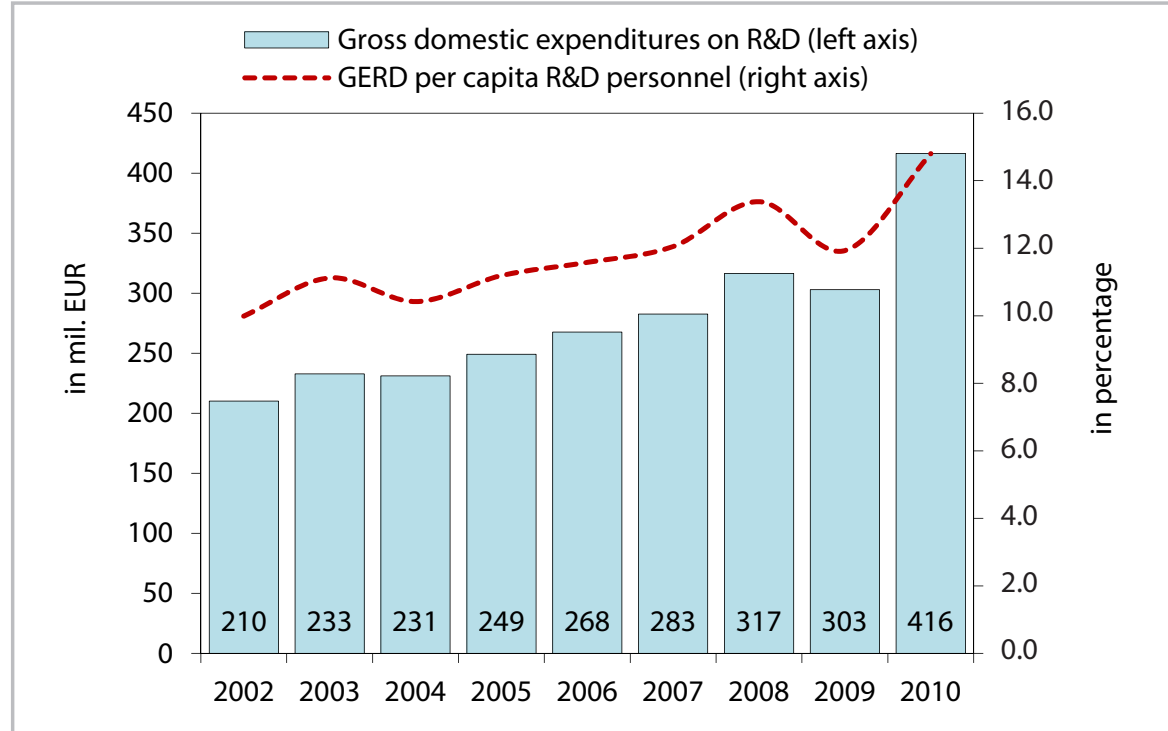

Figure 8 Expenditures on R \& D in Slovakia (2002-2010) Source: Author's calculation based on SOSR

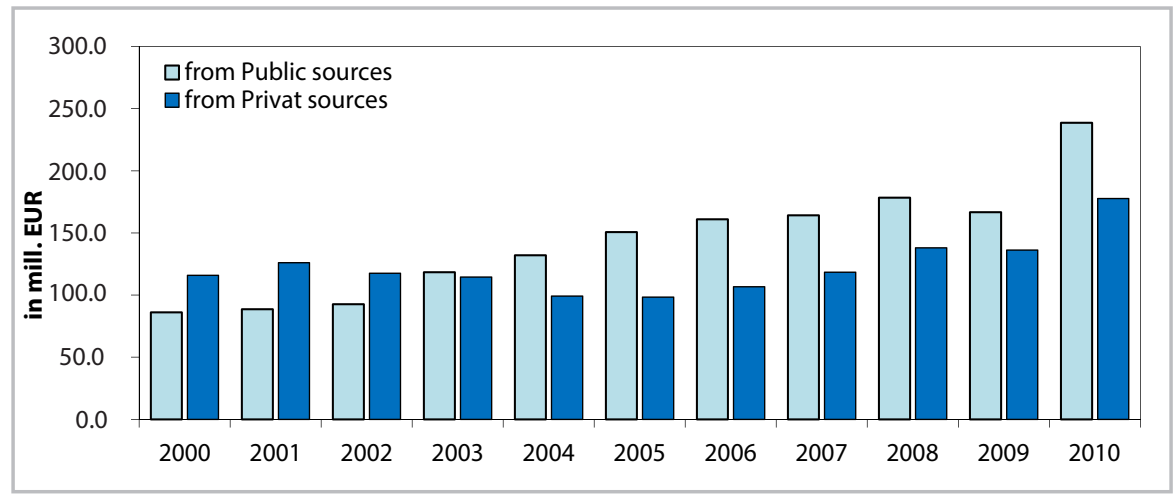

Figure 9 Expenditures on R \& D by the source of funding in Slovakia (2000-2010) in mil. EUR Source: Author's calculation based on SOSR

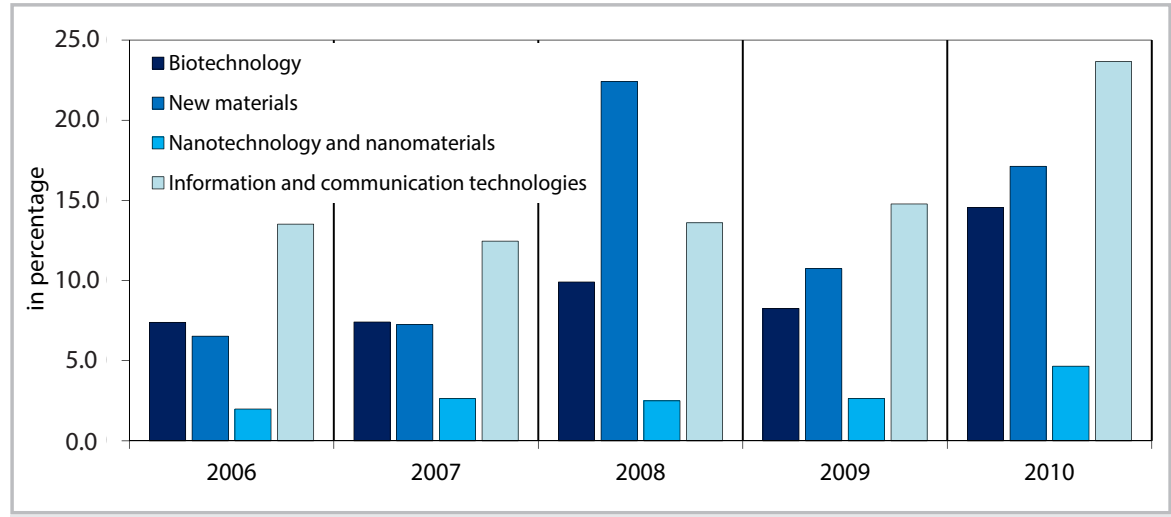

Figure 10 Public and private $R \& D$ expenditure in Slovakia (by area of performance) in percentage Source: 0 wn calculations based on SOSR data

demonstrates that the smart innovative policies should be directed on building the innovativefriendly environment that will encourage the private sector to invest and finance the innovative activities. This is indeed the track that Slovakia should follow as well. Furthermore, there is logical outcome that introduction of the taxation levies for SMEs with innovative approach and further improvement of the legal infrastructure (IP, property rights) could be some of the basic issues that needs to be addressed by the Slovak governmental institutions.

The pattern of $R$ \& $D$ expenditure during the period 2006-2010 (see Figure 10), indicates that expenditures on information and communication technology were constantly gaining the major share of the total $R$ \& $D$ financial sources (from $13.5 \%$ in 2006 to $23.7 \%$ in 2010). On the other hand, R \& D investments on the new materials were the second most supported area. During the observed period, their share varied from the lowest $6.5 \%$ in 2004 up to $22.4 \%$ in 2010 . Nanotechnology and nanomaterials were the least significant area of interest concerning to the $R \& D$, expenditures in that area remained constantly low throughout all observed years reaching the share of less than $5 \%$. Simultaneously, the pattern of the general $R$ \& $D$ expenditure shows that the major share of investments is directed into the innovative outcomes related to the area of the information and communication technology. This outcome is mostly related to the increasing share of private expenditures in that area, tending to adopt $R \& D$ to the market demand for the new information technology.

Analysis related solely to the public expenditure in the selected areas of $R$ \& D indicates somehow strategic priorities of governmental approach. Indeed, based on the share of expenditures dedicated to the selected areas, Slovak government during the observed period (2006-2008) funded mostly the research on biotechnology and new materials. Such indications in directing shows that Slovak government tends to develop areas of interest in which country may have competitive advantage compared to other nations. Contemplation of education system with the $R$ \& $D$ expenditures is another argument indicating the current pattern of the $R \& D$ expenditure. In the long-run it seems that $R \& D$ governmental approach tend to be based mainly on domestic research resources and it is less influenced by the FDI industry flow.

The $R$ \& D productivity is generally measured by the number of patents recorded in respective institutions. Globally, over the last decade (2000-2010) there were more than 7.3 million patents granted to the innovators worldwide. The most innovative economy during the same period was that of the United States introducing over 1.8 million patents. The Japan innovators followed with proximate number of patents (1.6 million). The global pattern (see Figure 11 ) shows that two thirds (74.4\%) of the total number of patents for the period 2000-2010 were granted to the most developed countries. The group of five largest economies consisting from USA (25.1\%), Japan (22.3\%), China (9.2\%), and EPO (7.8\%) were the most patent-innovating economies. 


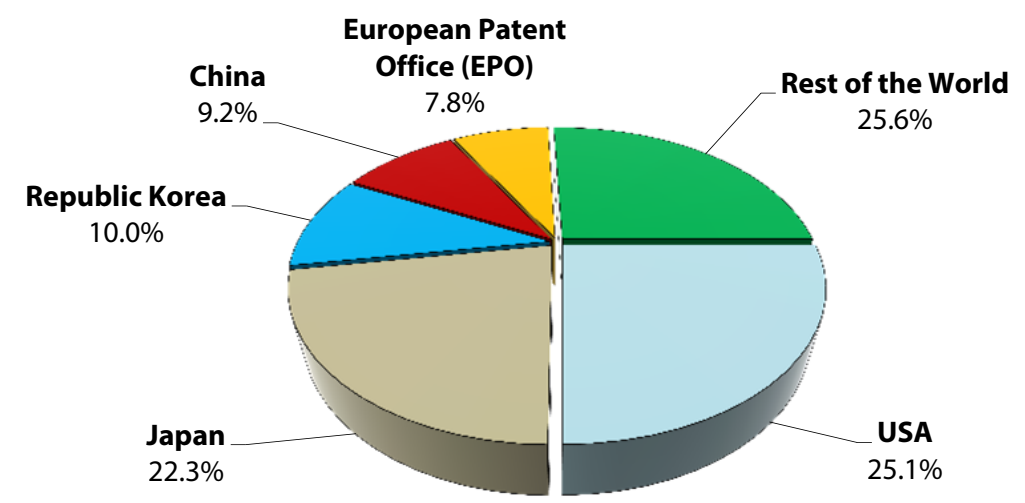

Figure 11 Share of the number of granted patents (2000-2010) Source: Author's calculation calculations based on WIPO

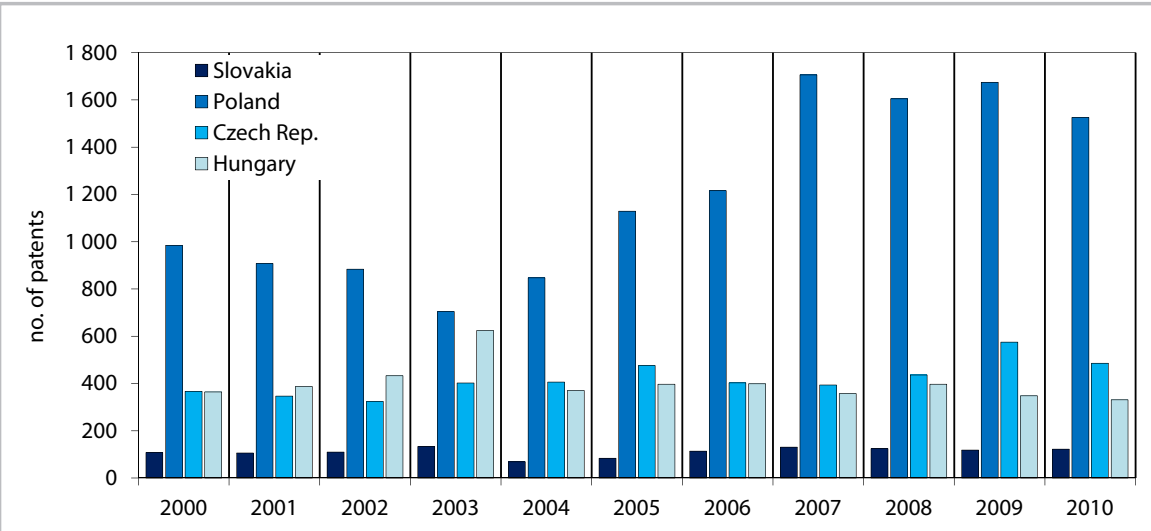

Figure 12 Granted patents in the V4 countries (2000-2010) Source: Author's calculations based on WIPO

Detailed analysis related to the Slovak R \& D productivity shows a discouraging outcome. The total of only 765 patents was granted to the Slovak innovators during the period 2000-2010. Annual averages of 70 patents were registered over the observed period in the domestic patenting office. The outcome of $R \& D$ productivity in Slovakia is the mirror of the expenditures dedicated to the $R$ $\& D$ during the same period. Therefore, the Slovak $R \& D$ productivity cannot be compared even with results of the neighbouring V4 countries. Lack of affirmative support (through GERD) and in particular creation of the friendly environment for the private investments in $R \& D$ remains the major obstacle shaping such a low $R \& D$ productivity. The figure below (see Figure 12) demonstrates a number of patents by each of $\mathrm{V} 4$ countries in the period between 2001 and 2010. The cross-country comparison with its neighbours lists Slovakia in the bottom of the list. It should be alleged that Poland is fearless leader in all observed years, estimating an output of 1,100 patents annually. Other V4 countries, the Czech Republic with 276 patents annually, and Hungary with 154 patents, anyhow estimated better outcome of the $R$ \& D productivity than Slovakia.

\section{Conclusion}

The outcome of this paper affirmed Slovakia as an economy undergoing the transitional phase from the efficiency-driven into the innovationdriven economic growth. During the last decade, the economic growth in Slovakia accelerated significantly as the result of successful market reforms. Obviously, market reforms transformed Slovakia into an attractive business environment for both foreign and domestic investments. Economic growth during that period was driven by the intensive inflow of the FDI. An annual average of 3.5 billion US\$ were entering Slovakia in the form of FDI. It generated employment, rising incomes, job opportunities, improved infrastructure and living conditions. In particular, accession of Slovakia in the EU (2004) should be considered as a crucial breakthrough of the country on its way to achieve sustainable economic growth. Hand to hand with foreign investments, findings of this thesis evidenced an increasing opportunity for the domestic driven entrepreneurship. Since its EU accession, more than 8,900 enterprises were established annually in Slovakia. Currently, there are performing 143 thousand enterprises, and the small and medium enterprises (SMEs) constitute the major part of business entities operating in Slovakia. A positive indication is increasing share of foreign owned enterprises, demonstrating the trust of foreign entrepreneurs in the political, economic and social potential of Slovakia. In recognizing the role of innovation in accelerating its economic growth, Slovak government designed the national innovation strategy. Improvement in the quality of the innovation infrastructure, higherquality of human resources and efficient use of innovation investments were highlighted as the basement of the innovation strategy. This strategy is in line with the major goals of the "European strategy for smart, sustainable and inclusive growth - Europe 2020" aiming at development based on knowledge and innovation, efficient economy, generating employment and better territorial cohesion. All of these goals meet the current Slovak economic constraints evidenced in this thesis.

Despite the recognition of the major concerns and designing innovation developing goals, less of the practical implementation took place until now. Public funding of the $R \& D$ remained very low $(0.63 \%$ of GDP), despite the significant increase of the available $R \& D$ public funds (doubled since 2004). Private sourced $R$ $\& D$ did not follow the government trends. The ratio of the public/private $R \& D$ remained very high (57\%). Conversely, in the innovation-driven economies of the Northern Europe (such as that of Finland) the share of public $R$ \& $D$ expenditure is significantly lower (4.4\%). The most supported field of $R$ \& $D$ in Slovakia during the last five years was information and communication technology (23.7\% of total public and private R \& D in 2010) followed by the $R \& D$ investments in the area of new materials (22.4\%) and biotechnology (15\%).

Apparently, the output of the $R$ \& D remained at discouraging figures during the last decade. 0 nly 70 patents annually were granted to the Slovak innovators during the period 2000-2010. Cross country comparison with the $V 4$ regional economies indicates the low $R$ \& $D$ productivity. Despite the low output in $R \& D$, Slovakia had significantly better performance related to the FDI technology transfer. Taking into account the large inflow of FDI during the last decade, the widespread gains from the FDI technology spillower should be stressed out. 
Additionally, during the last four years Slovakia was listed within the top 15 countries globally - benefiting the largest impact from the FDI technology transfer.

Competitiveness is one of the major benefits that innovation generates. Based on the comparative analyses (with Finland), the main deficiencies of the Slovak competitiveness are related to the areas where the governmental influence is dominant. In particular, further improvement of the public governance, building of the modern infrastructure and support of the higher education system remains the main challenges of national competitiveness. Therefore, in order to cope with the future challenges of the innovative-driven growth, Slovakia should seriously consider improvement of the scientific infrastructure and the allocation of larger share of funding $R \& D$ from both public and private sources.

\section{Acknowledgment}

This work was co-funded by the European Community under the project no 26220220180: Building Research Centre „AgroBioTech“.

\section{References}

BLOMSTRÖM, M. - KOKKO, A. - ZEJAN, M. 2000. Foreign Direct Investment: Firm and Host Country Strategies. New York: Palgrave Macmillan, 2000. 268 p. ISBN 978-031223141-5.

BLOMSTRÖM, M. - KOKKO, A. 2003. The Economics of Foreign Direct Investment Incentives. In Foreign Direct Investment in the Real and Financial Sector of Industrial Countries. Heidelberg: Springer-Verlang, 2003. pp. 37-56. ISBN 3-540-00510-2.

BROWN, T. - ULIJN, J. 2004. Innovation, Entrepreneurship and Culture: The Interaction between Technology, Progress and Economic Growth. Cheltenham: Edward Elgar Publishing Limited, 2004. 255 p. ISBN 1-84376-346-X.

ERNST \& YOUNG. 2011. Next generation Innovation Policy: The future of EU innovation policy to support market growth. [online] [cit. 2011-11-14]. Available at: <http:// www.ceps.eu/book/next-generation-innovation-policy-future-eu-innovationpolicy-support-market-growth>

GAULT, F. 2010. Innovation Strategies for a Global Economy: Development, Implementation, Measurement and Management. Cheltenham: Edward Elgar Publishing Limited, 2010. 232 p. ISBN 978-1-84980-036-5.

G00D, P. 2005. Introduction to statistics through resampling methods and Microsoft Office Excel. New Jersey : John Wiley \& Sons Inc, 2005. 231 p. ISBN 978-0-471-73191-7.

MAXWELL, I. 2009. Managing Sustainable Innovation: The Driver for Global Growth. Springer, 2009. 208 p. ISBN 978-0-387-87580-4.

MCDANIEL, B. 2002. Entrepreneurship and Innovation: An Economic Approach. New York: M E Sharpe Inc, 2002. 328 p. ISBN 978-0-7656-0709-6.

PORTER, M. 1990. The Competitive Advantage of Nations. In Harvard Business Review, vol. 68,1990, no. 2, pp. 73-93.

SARI0-b (Slovak Investment and Trade Development Agency). 2011. Why invest in Slovakia. [online] [2011-10-18] Available at: <http://www.sario.sk/?why-invest-in-slovakia>

SIEBERT, H. 2007. The World Economy: A global analysis. New York: Routledge, 3rd ed., 2007. 464 p. ISBN 978-0-415-40282-8.

SOM, 0. 2012. Innovation without $R$ \& D: Heterogeneous Innovation Patterns of Non- $R$ \& D-Performing Firms in the German Manufacturing Industry. Wiesbaden : Springer Gabler Verlag, 2012. 479 p. ISBN 978-3-8349-3491-8.

SYKES, M. 2004. Understanding Economic Growth: Macro-Level, Industry-Level, FirmLevel. Paris : OECD Publishing, 2004. 168 p. ISBN 978-1-403941473.

WEIERS, R. 2008. Introduction to Business Statistics. Mason: South-Western College Pub, $7^{\text {th }}$ ed., 2008. 880 p. ISBN 978-0-538-45217-5

\section{Statistical sources}

TOTAL R \& D expenditure (GERD) by sectors of performance [in million EUR]. [online] [cit. 2012-01-05] Available at: <http://appsso.eurostat.ec.europa.eu/nui/show. do?dataset=rd_e_gerdtot \& lang=en>

PROPORTION of innovative enterprises, 2008. [online][cit. 2012-01-05] Available at: $<$ http://appsso.eurostat.ec.europa.eu/nui/show.do?dataset=inn_cis6_type\& lang=en>

SOF (Statistical Office of Finland). Research and development statistics: $R \& D$ personnel and expenditure. [online][cit. 21-01-25] Available at: <http://tilastokeskus.fi/til/ tkke/tau_en.html>

SOSR (Statistical Office of the Slovak Republic). Indicators of Economic Development. [online][cit. 21-01-25] Available at: <http://portal.statistics.sk/showdoc. do?docid $=3013>$

WIPO (World Intellectual Property Organization). Statistics on Patents. [online][cit. 201202-15] Available at: <http://www.wipo.int/ipstats/en/statistics/patents/>

WORLD BANK. 2011. WDI: Bank nonperforming loans to total gross loans (\%). [online] [cit. 212-01-05] Available at: <http://data.worldbank.org/indicator/FB.AST.NPER.ZS>

World Development Indicators: GNI per capita, Atlas method (current US\$). [online][cit. 2011-12-28] Available at: http://data.worldbank.org/indicator/NY.GNP.PCAP.CD

\section{Contact address}

*Ing. Kushtrim Braha, MBA, Slovak University of Agriculture in Nitra, Faculty of Economics and Management, Department of Economics, Trieda A. Hlinku 2, 94976 Nitra, Slovak Republic, e-mail: kbraha@gmail.com 